\title{
Beritan Aşireti Halı ve Kilimleri
}

Öğr. Gör. Dr. Elif Aksoy

Makale Geliş Tarihi: 04.08.2015

Yayına Kabul Tarihi: 27.04.2016

\section{Öz}

Bu makalede, Diyarbakır, Urfa, Adıyaman ve Elazı̆̆’n Kovancılar yöresinde ikamet eden, yaylak ve kışlak hayatı yaşayan Beritan aşiretinin halı ve kilimleri incelenmektedir. Bu çalışmanın amacı, ülkemizde yeterince tanınmayan Beritan aşireti dokumalarını tekstil literatürüne kazandırmaktır. Ayrıca mevcut dokumaları gelecek nesillere aktarmak ve geleneksel dokuma sanatları içinde bir yer edinmesini sağlamaktır. Elazığ’n Kovancılar ilçesinde yapılan araştırma ve inceleme gezileri, nitel araştırma metodu ile oluşturulmuş bu çalışmanın, veri toplama aracı olmuştur. Alan araştırmaları sonucunda köyden kente göçlerin arttığı, yakın dönemdeki sosyal ve ekonomik değişimlerin yansımaları, dokuma işleminin zor bir iş olması ve hayvancılık işi ile uğraşmalarından dolayı Beritanlıların dokuma sanatını bıraktıkları ortaya çıkmıştır.

Anahtar Sözcükler: Beritan Aşireti, Kovancılar, Halı, Kilim, Yaylak-Kışlak

\section{CARPETS AND RUGS OF BERITAN TRIBE}

\section{Abstract}

The carpets and rugs of Beritan tribe, who live the life of pasture and wintering and reside in Diyarbakır, Urfa, Adıyaman and Kovancılar vicinity of Elazığ, are examined in this article. The purpose of this study is to introduce the weavings of Beritan tribe, which are not known enough in our countrywill have been added to the textile literature; in addition, to pass them on the future generations and to provide them finding a place among the traditional weaving arts. The research and study tours held in the Kovancilar town of Elazı $\breve{g}$ became the means of data gathering for this study, which was created through the qualitative research methods. As a result of the field studies, it emerged that the rural urban migration increased and Beritanians ceased the art of weaving due to the reflections of social and economic changes in recent times, weaving to be a hard job and they engaged in livestock.

Keywords: Beritan Tribe, Kovancilar, Carpet, Rug, Pasture-Wintering 


\section{Giriş}

Beritan aşireti Güneydoğu ve Doğu Anadolu'nun en eski göçebe aşireti (Balıkçı, 2000) olmakla beraber Türkiye'nin en büyük göçebe topluluğudur (Thevenin, 2011: 1). Beritanlılar yaz aylarında Bingöl-Karlıova yaylak alanlarında, kış aylarında Elazığ, Diyarbakır ve Urfa üçgeninden oluşan kışık alanlarda (Resim 1) ikamet etmektedirler (Thevenin, 2011: 11). Beritan aşireti dokumalarını çalışmamızın başlıca nedeni, ülkemizde çok az tanınan ve 600 yıldan beri Anadolu'da yaşayan Beritan aşiretinin kendine özgü kültürünü ve dokumalardaki motiflerini, Anadolu'nun diğer bölgelerindeki dokumalarla olan ilişkisini ortaya çıkarmaktır. Bu dokumaları tekstil literatürüne kazandırmak amacı ile Elazığ'ın Kovancılar ilçesinde alan araştırmaları yapılmıştır. Bazı kaynaklarda Beritan Aşiretin kökeninin Orta Asya'dan gelen Türkmenler olduğu, Beritanlıların Bozulus'a bağı olduğunu belirtmekle beraber (Taşdelen, 1997: 45) aşiretin kendine ve hayvanlarına yeni yurtlar ve yeni otlaklar aramaları sebebi ile Anadolu'ya geldiklerinden söz edilmiştir. Bozulus, Akkoyunlulardan kalma büyük kısmı Bayundur boyuna dayanan Türkmen halkına Osmanlı defter kayıtlarında verilen isimdir (Erenoğlu, 2010: 187).Bayundur boyu Oğuz Kağan destanına göre Oğuzların 24 boyundan biri ve Kaşgarlı Mahmud'a göre Divan-ı Lügati't Türk'deki 22 Oğuz boyundan üçüncüsüdür (Atalay, 2006: 56). 16. yüzyılda Bozuluslar, Safavilerin yönlendirmeleri ile yoğun şekilde Azerbaycan'ın zengin topraklarına doğru göç etmişlerdir. Celali isyanları sırasında (1596-1610) ve sonrasında göç yönünün Anadolu'ya döndüğg̈ kaydedilmiştir (Sümer, 1957: 429-447-Woods, 1999: 41)

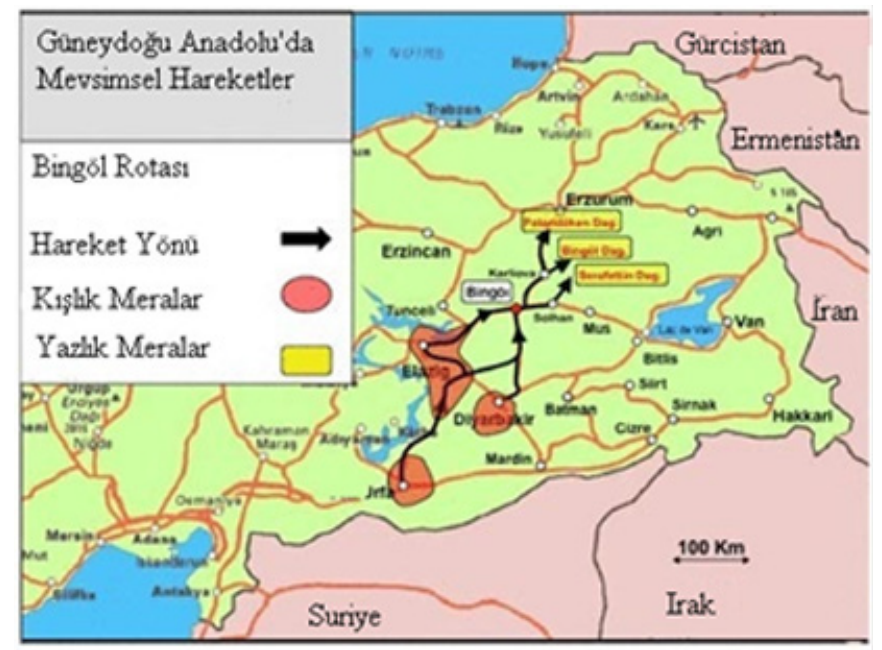

Resim I. Beritanlıların Mevsimsel Hareketleri (Thevenin 20I I: 5) 
Kültür, bir toplumun üyesi olarak insan tarafından kazanılan alışkanlık, kabiliyet, adet, sanat, inanç ve bilgiyi içeren etnografik bir algıdır (Stocking, 1968: 73). Bu bağlamda, farklı değer ya da kültüre sahip toplumsal veya etnik gruplar arasındaki doğrudan ve sürekli temasın sonucunda, gruplardan biri veya diğerinin ya da her ikisinin birden diğer gurubun kültürünü, kültürel özelliklerini toptan veya kısmen benimsemesi sürecine kültürlenme adı verilir (Kongar, 1994: 13-37). Beritan aşireti de Orta Asya'dan Anadolu'ya göç eden bir Türkmen boyu olarak Anadolu'ya gelirken çadırlarını, yetiştirdikleri hayvanları, göçebe ve yerleşik yaşayışa ait kültürlerini, kıyafetlerini, edebi değerlerini, törelerini ve el sanatlarını da getirmişlerdir. Dolayısıyla Beritan dokumalarındaki motiflerin Anadolu dokumaları ile benzerlik göstermesi topluluklar arasındaki etkileşimin ve kültürlenmenin sonucudur.

Beritan aşiretinin hayvancılıkla uğraşan kesimi yaylalara mayısın son haftası ile haziranın ilk haftası çıkmaktadır. Aşiret halkı yaylada 4-5 ay kalır. Eylülden sonra yayladan ayrılıp Diyarbakır ve Urfa'ya göç ederler. Beritan aşiretinin yerleşik olanların yanında kış aylarını hala çadırlarda geçiren bir kesimi de bulunmaktadır. Mayıs ayı gelince Diyarbakır ve Urfa da yaşayan Beritan aşiretinin bir kolu tekrar yaylaya göç eder. Amaç hayvanları serinde tutmaktır. Çünkü hayvanlar serinde tutulmadıklarında ya da sıcak su içtiklerinde zerik denilen bir hastalığa yakalanmaktadırlar. Aşirette evlilikler genellikle akraba evliliğidir. Aşiretin okuma-yazma oranı çok yüksektir. Eğitim ve öğrenime önem verirler. Ağalık olayı yoktur (Canpolat, 2014).

Aşiretteki kadınların dokudukları kilimler ve halılar yaylak kışlak hayata uygun olarak yapılmıştır. Beritan konar-göçerleri, yaz mevsiminde hayvanlarını beslemek için yaylalara çıktıklarında bu dokumalarıçadırlarında kullanmaktadırlar. Aşiret dokumalarında kullanılan motifler Anadolu'da dokunan birçok halı ve kilimin motifleri ile benzerlik göstermektedir.

\section{Aşiretin Tarihçesi}

Beritan Aşireti liderlerinin ifadelerine göre aşiret Türkiye'ye Bağdat yakınlarında Mezfere civarında olan Bert veya Bırt isimli bir bölgeden gelmiştir. Beritanlılar ilk önceleri Diyarbakır'ın Karacadağ ve Urfa bölgesinde ve çevresinde yaşamışlardır. Aşiretin isminin ilk önceleri Qemikan (Qemıkî) olduğu söylenmektedir. 1620 ile 1640 yılları arasında Doğu Anadolu Bölgesinde Celali ayaklanması olmuştur. Bu ayaklanmayı çok kanlı bir şekilde bastıran IV. Murat, bu bölgede ayaklanmaya destek veren aşiretlerin birçoğunu İç Anadolu'ya sürgün etmiştir. Bu sürgünden Beritanlılar da nasibini almıştır (Erhan, 1992: 124-129). Konya yöresine sürgün edilen Beritanlılar burada uzun bir zaman kalmışlardır. Bir kısım 
Beritanlıların Konya'da kaldıkları da söylenmektedir (Sorgucu, 2014). Fakat o bölgede Beritan aşiretinin, Karamanoğulları ve Osmanoğulları beylikleri ile çatışmaları sonucu sürüleri ve tüm oymak halkı ile birlikte tekrar Urfa bölgesine yerleşmişlerdir. Burada yarı göçer ve yarı yerleşik durumda çadır hayatı sürdürmüşlerdir. Kışı Urfa yöresinde, yazı da sürüleri ile Şerafettin dağları, Bingöl ve Karlıova yaylalarında büyük çadır ve obalar halinde yaşamaktadırlar (Taşdelen, 1997: 28). Beritanlılar günümüzde yoğun olarak Elazığ, Malatya, Adıyaman, Urfa ve Diyarbakır illerinde yaşamlarını sürdürmektedirler. Bazı kaynaklarda aşiretin kökeninin Orta Asya olduğu söylense de aşiretin ileri gelenleri bu iddia hakkında pek fazla yorum yapmamaktadırlar.

Beritan aşiretinin geçmişi ile ilgili kaynaklar son derece kısıtlı olmakla birlikte göçer aşiretlerin kökenini tespit etmek de son derece zordur. Ancak aşiretin varlığı hakkında bilgiler Osmanlı devletinin son dönem arşiv kayıtlarından elde edilmiştir. Osmanlı arşivlerine göre 20. yüzyılın başlarında Beritan aşiretinin Diyarbakır ve Urfa arasındaki bölgede yaşadığı anlaşılmaktadır (Başbakanlık Osmanlı Arşivi). Aşiretin adı ile ilgili olarak Beritan ve Birtı kelimeleri kullanılmaktadır. Bu adların anlamları konusunda pek fazla bilgi yoktur. Sözlüklerde Beritan kavramına yakın Beri ve Beriqan kavramları bulunmaktadır. Beri'nin "önce "ve "çöl" olmak üzere iki anlamı vardır. Beriqan ise "hayvan sağmak için otlağa giden kimse" anlamındadır (Taşdelen, 1997: 27). Anadolu göçer toplulukları üzerine yapılmış araştırmaların birçoğu Güney Anadolu, Güneydoğu Toroslar ve Batı Anadolu'da yaşayan Avşar (Aktan,1995: 255-262), Çepni (Melikoff, 1998: 1-10) Barak (Kır 2003: 219-240), Tahtacı (Mutlu, 2011: 15031511) vb. isimlerle anılan Türkmen ve Yörük olarak gruplanan, göçer, yarı göçer veya yerleşik olan boy ve aşiretlerle ilgilidir. Bugüne kadar ülkemizde konarlar-göçerler ve aşiretler konusunda yapılmış pek çok çalışma olmakla birlikte bunlar daha çok tarih, coğrafya, halkbilim ve sosyoloji bilimlerinin ilgi alanlarında kalmaktadır (Kutlu, 1987: 129-140).

Genel olarak Orta Doğu'da göçebe toplumlarla ilgili araştırmalar, mera tahsis örneğini göstermek ve bu toplulukların belli haklara sahip olduklarını vurgulamak için yapılmıştır. Bu haklara bir kabile ya da grubun tüm üyeleri sahiptir. Beritanlılar kendilerini yazlık ve kışlık otlaklar arasında hayvan sürüleri ile birlikte göç eden gerçek göçebeler olduklarını ifade etmektedirler. Beritanlılar göçebe ve çingene gibi evcil hayvan sürüleri olmadan göç eden kişilerden kendilerini farklı gördüklerini ifade etmektedirler (Skogseid, 1993: 216-231). Bu yüzden göçer, göçebe ve yaylacı gibi sözcükleri açıklamak, karışıklığı önlemek için yerinde olacaktır. Belirli bir mekânı olmaksızın çadır, hayvan ve sair araçlarıyla mevsime göre sürekli yer 
değiştiren topluluğa göçebe denir. Yaylak ile kışlak arasında mevsimine göre mekik dokuyan kişiler konar- göçer olarak tanımlanmaktadır (Ipek, Şimşirgil, Gülsoy, Taştemir 2013: 76). Yaylacılar, sadece bir noktadaki yaylalarına sayfiye veya hayvancılık amaçlı gidip, kış yaklaştığında tekrar devamlı yerleşmelerine dönerler (Hadimli, Karakuzulu, Birinci, 2010: 351). Beritan aşireti de göçer olan sadece yaz aylarında hayvanlarını otlatmak için kendilerine ait meralarına çadır kuran, kış gelince de yerleşik oldukları yerleşmelerine geri dönen bir topluluktur.

\section{Çalışmanın Amacı}

Bu makale, ülkemizde çok bilinmeyen Beritan dokumalarını geleceknesillere tanıtmak ve bu dokumaların geleneksel dokuma sanatları içindeki yerini belirleyebilme amacını hedeflemektedir. Beritan dokumaları yaylalarda sadece aşiretin ihtiyaçlarını karşılamak amacıyla üretilmesi sebebiyle bugüne değin fazlaca dikkat çekmemiş ve incelenmemiştir. Ayrıca bu konu ile ilgili kaynaklar ve araştırmalar az olup, Beritan dokumaları ile ilgili bilgi, resim, şekil ve şema gibi örnekler de literatürde bulunmamaktadır. Bu çalışma ile bu güne kadar ele alınmamış olan Beritan dokumaları tekstil literatürüne kalıcı belgelerle tanıtılmış olacaktır.

\section{Çalışmanın Kapsamı}

Çalışmanın kapsamını makalenin konusu olan Beritan kilimleri ve halıları oluşturmaktadır. Beritan kilimleri ve halıları hakkında şimdiye kadar kapsamlı bir araştırma yapılmamıştır. Bu nedenle Beritan halı ve kilimlerini, tekstil literatürüne kazandırmak ve bu dokumalardaki motifleri Anadolu'nun diğer bölgelerindeki dokumaların motifleri ile olan benzerliklerini ortaya koymak amacıyla böyle bir çalışma yapılması uygun görülmüştür.

\section{Materyal ve Metot}

Nitel araştırma yöntemi ile oluşturulmuş bu çalışmada veri toplama aracı olarak Elazığ ve Elazı ̆̆'ın Kovancılar ilçesinde alan araştırması yapılmıştır. 2014 yılının Ekim ve Kasım aylarında Beritan aşiretinin eskiden yapılmış olan dokumalarını literatüre kazandırmak için Elazığ'da ve Kovancılar ilçesinde araştırma ve inceleme gezileri gerçekleştirilmiştir. $\mathrm{Bu}$ alan araştırmalarında Beritan aşiretine ait 3 adet kilim ve 2 adet halı incelenmiştir. Beritan aşiretinin kendine has kültürünü ve dokumalarını incelemek için Beritanlılarla röportaj yapılmış, dokumaların fotoğrafları çekilmiş̧ir. Ayrıca dokumaların dokuma tekniği, hammadde, sıklık, boyut, renk ve kompozisyon özellikleri konularında ayrıntılı inceleme yapılmıştır. Bu konu ile ilgili yayın yapmak isteyen araştırmacılar ve gelecek kuşaklar 
için dokumaların kayıt altına alınması tartışımaz bir gerçektir. Bu yüzden araştırmada kültürel bir miras olan Beritan aşiretine ait halı ve kilimlerin desenleri bilgisayar programında çizilerek motiflerin gelecek kuşaklara aktarılması sağlanmıştır. Dokuma türleri, dokumada kullanılan araç ve gereçler, uygulanan dokuma teknikleri, renk, desen ve motif adları çizim ve fotoğraflar ile sunulmuştur. Aşiret halkının yoğun olduğu Elazığ ve ilçesi Kovancılarda 3 adet kilim ve 2 adet halıya ulaşılmıştır. İncelediğimiz yerlerde Beritan aşiretine ait başka dokumalara rastlanılmamıştır.

\section{Beritan Aşireti Halı ve Kilimleri}

Küçükbaş hayvancılıkla geçimlerini sağlayan Beritanlılar, aşiret hayatında önemli bir yere sahip olan geleneksel birçok dokuma türünü (halı, kilim, cicim) günümüze kazandırmışlardır (Aksoy, 2012: 301). Beritan halı ve kilimlerinde kullanılan çözgü ve atkı iplikleri yündür. Bu iplikler Karaman koyunundan elde edilmiştir. Yıkama, eğirme, boyama gibi hammadde işlemleri aşiretin kadınları tarafından yapılmışır. Dokumalar, yer tezgâhı denilen genellikle yaylak kışlak hayatı süren aşiretlerin kullandığı tezgâh tipi ile dokunmuştur. Anadolu'nun çeşitli yörelerinde konar-göçer tezgâh ya da yatık tezgâh adını alan bu tezgâh, Orta Anadolu'da dolak, Güney Anadolu'da yer istarı, Doğu Anadolu'da yer tezgâhı, yer mazmanı, teven, koni, spi gibi adlarla bilinmektedir (Eşberk, 1939: 103; Durul, 1969: 33;Beşikçi, 1969: 136; Gül, 1976: 110; Yalgın, 1977: 472; Yağan, 1978: 219).

Beritan dokumalarında ilme soldan sağa doğru atılmaktadır. İlmeyi soldan sağa atmak demek Batı Anadolu tipi demektir, yani Türk düğümüdür. Bevş ağacı (=bevşik=varangelen) adı verilen bir ahşap gereç ile sırasıyla iki gruba ayrılan çözgü ipliklerinde ağızlık açılır, renkli ipliklerden çolma edilip, aralarında atkı (argaç) atılarak dokunur. Illmelervarangelen yani bevşik ağacı aşağıdayken atılmaktadır. Dokunan kısımlarda ilmelerin sık ve sağlam olması için her atkı geçirildikten sonra, ilmeler aşağı doğru kirkitle dövülür. "Kirkitleme" adı verilen bu işlem, dokuma tamamlanıncaya kadar her sıradan sonra sürdürülür. Dokuma sırasında kullanılan diğer bir araç da "biş" dir. Biş ve kirkit demirden yapılmıştır. Kirkite benzeyen biş, özellikle kilim kısımlarının sıkıştırılmasında kullanıldığı gibi, karışan, kayan çözgü ipliklerinin düzeltilmesinde de kullanılmaktadır (Resim 2). Eğer halı dokunuyorsa, dokumada hav kısımları 1 veya 2 sırada bir makasla kesilir. 


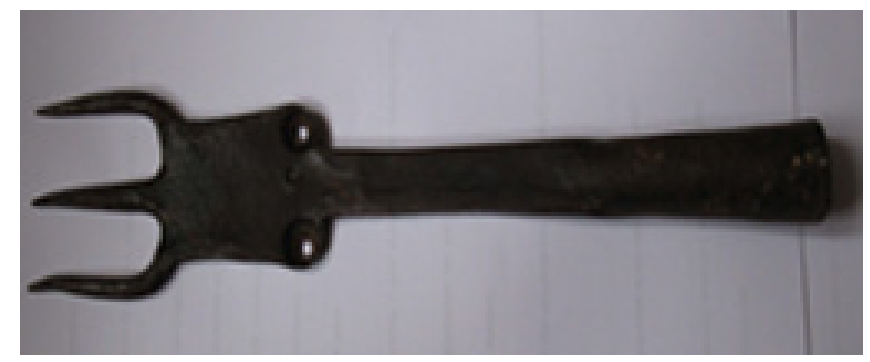

Resim 2. Biş

Kilim, motiflerin bulunduğu alanlarda renkli atkı ipliğinin, çözgünün bir alttan bir üstten geçirilmesi ve başka renkteki motifin sınırından geri dönmesiyle dokunur. Bu şekilde farklı renkteki atkı ipliğiyle kendi desen sınırı içinde motifler meydana getirilir (Aytaç, 2000: 91). Motifler dokuyucunun isteğine göre bölümler halinde dokunabilir. Aşirette dokunan diğer bir dokuma tekniği de halıdır. Beritan aşireti halılarında ilme ipliği bir çözgü çiftinin (ön ve arka telin) etrafından dolanarak uçları arkadan öne doğru alttan çıkarılarak atılır (Resim 3). Sağ elle tutulan çözgü çiftinden sol eldeki ilme ipliği önce arka telin sonra ön telin etrafından dolandırılır (Aytaç, 2000: 57).

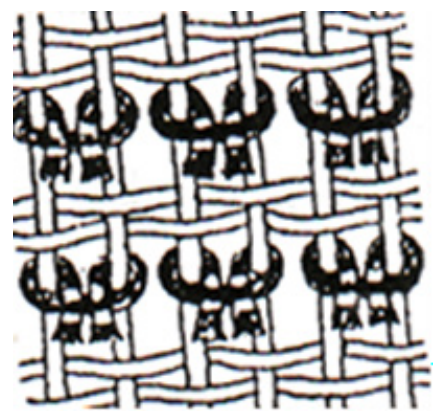

Resim 3. Türk Düğümü (Aytaç, 2000: 57)

Kilimlerde kullanılan renkler, lacivert, mavi, beyaz, kırmızı, sarı, kahverengi, nohut rengi, turuncu ve pembedir. Halılarda dokuma başlarken ilk önce çiti yapılır. Daha sonra $3 \mathrm{~cm}$ ile $7 \mathrm{~cm}$ arasında kilim örgüsü dokunur ve halı dokumasına geçilir. Halıların hav uzunluğu $1 \mathrm{~cm}$ 'dir. Halıların kıyı kolonunda 2 çift çözgü teli bulunmaktadır. Halı ve kilimlerin uzunluğu ise, yine aynı şekilde isteğe göre ayarlanmaktadır. Dokumaların tümünde görülen ortak özellik, atkı ve çözgülerinin yün, saçakların uzun ve örgülü oluşudur. Çözgü ipliklerinin başlangıç ve bitiş uçları halı saçaklarını oluşturur. Çözgü uçlarının birkaçı bir araya getirilip, bağlanmasıyla çeşitli şekillerde ve değişik uzunlukta $(10-15 \mathrm{~cm})$ saçaklar yapılır. Çoğunlukla 
aşiret halılarında görülen bu özellikler, göçebe halıları karakterini taşımasıyla açıklanmaktadır (Haack, 1975: 21-35).

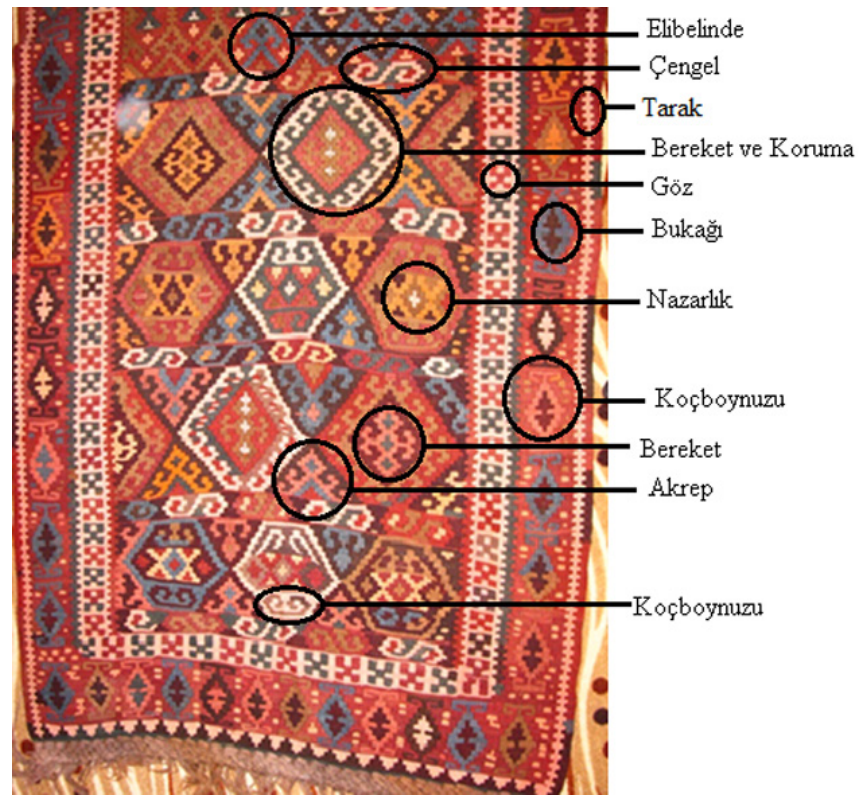

Resim 4. Beritan Kilimi, $123 \mathrm{~cm} \times 420 \mathrm{~cm}$, Elazı̆̆ (Kovancılar), Bozan Kantarcıoğlu'nun arşivinden

Resim 4'teki Beritan kilimi $123 \mathrm{~cm} \times 420 \mathrm{~cm}$ boyutlarındadır ve kilim tekniği ile dokunmuştur (Resim 4). Dokumanın bordürleri koçboynuzu, bukağı, göz-zülüf ve tarak-parmak motifleri ile süslenmiştir' (Erbek, 2002: 37, 79, 132, Durul, 1969: 24, Anatolian Kilims, 2005: 22). Zeminde ise, elibelinde ${ }^{2}$, çengel, bereket ve koruma-çengelli baklavaejderha $^{3}$, nazarlık-göz ${ }^{4}$, akrep -canavar izi ${ }^{5}$ ve koç boynuzu motifleri yer almaktadır (Anatolian Kilims, 2005: 25, 97, 122, 176; Erbek, 2002: $27,140,126,156)$. Dokumanın atkı ve çözgüsü yün olmakla beraber, ortalama olarak $10 \mathrm{~cm}$ ' deki çözgü sayısı 28 tel ve $10 \mathrm{~cm}$ ' deki atkı sayısı 66 'teldir. Dokumada kullanılan renkler lacivert, mavi, beyaz, kırmızı, sarı, kahverengi, nohut rengi ve pembedir (Resim 5).

'T.C Kültür ve Turizm Bakanlığı, Anatolian Kilims, 2.cilt

${ }^{2}$ T.C Kültür ve Turizm Bakanlı̆̆ı,Türk El Dokuması Halılar, 2. cilt

${ }^{3}$ T.C Kültür ve Turizm Bakanlığı, Anatolian Kilims, I.cilt

${ }^{4}$ T.C Kültür ve Turizm Bakanlığı, Anatolian Kilims, 2.cilt

${ }^{5}$ T.C Kültür ve Turizm Bakanlığı, Anatolian Kilims, 2.cilt 


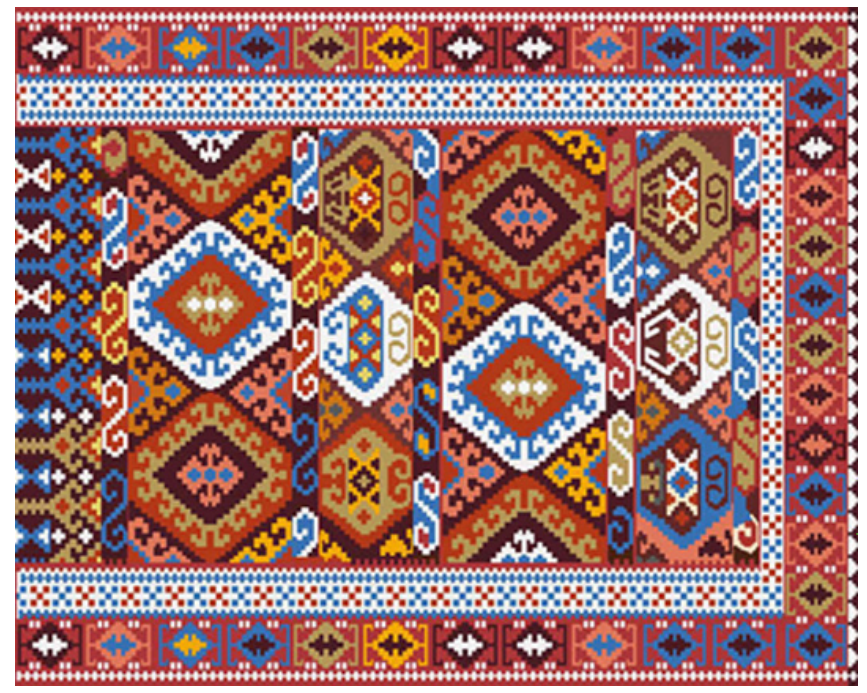

Resim 5. Resim 4'deki Beritan Kiliminin Bilgisayar Programında Çizimi

Resim 6'daki kilim $56 \mathrm{~cm} \times 110 \mathrm{~cm}$ boyutlarındadır. Dokumada 3 bordür bulunmaktadır. Bordürlerde elibelinde ${ }^{6}$ ve koçboynuzu ${ }^{7}$ Anatolian Kilims, 2005: 119) motifleri görülmektedir (Türk El Dokuması Halılar, 2006: 11). Dokumanın zeminine ise akrep, göz, koçboynuzu ve yılan-suyolu ${ }^{8}$ motifleri yerleştirilmiştir (Anatolian Kilims, 2005: 31, Türk El Dokuması Halılar, 2006: 11; Erbek 2002: 32, 106, 132, 156; Durul, 1969: 24). Kilimin atkı ve çözgüsü yün olmakla beraber, ortalama olarak $10 \mathrm{~cm}$ ' deki çözgü sayısı 31 tel,10 cm' deki atkı sayısı 66 teldir. Dokumada kullanılan renkler pembe, beyaz, lacivert, turuncu, kırmızıdır (Resim 6-7).

${ }^{6}$ T.C Kültür ve Turizm Bakanlığı,Türk El Dokuması Halılar, 2. cilt

${ }^{7}$ T.C Kültür ve Turizm Bakanlığı, AnatolianKilims, 2.cilt

${ }^{8}$ T.C Kültür ve Turizm Bakanlığı, AnatolianKilims, I. cilt 


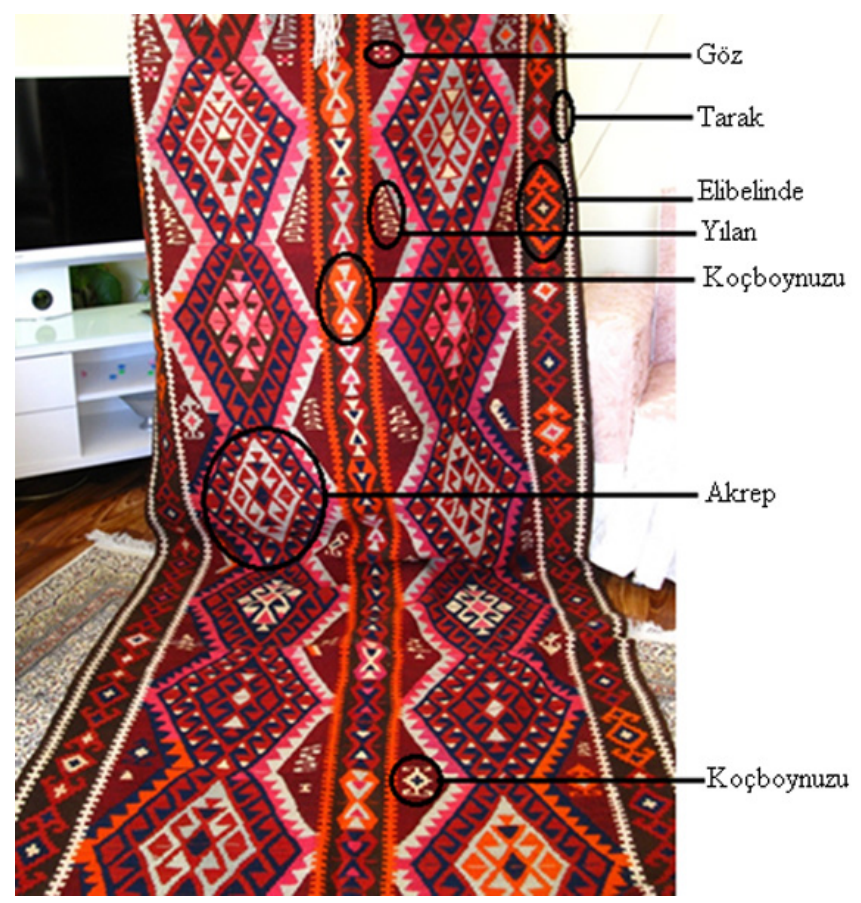

Resim 6. Beritan Kilimi, $56 \mathrm{~cm}$ xI I0 cm, Elazı̆̆ (Kovancılar), Bozan Kantarcıoğlu'na ait

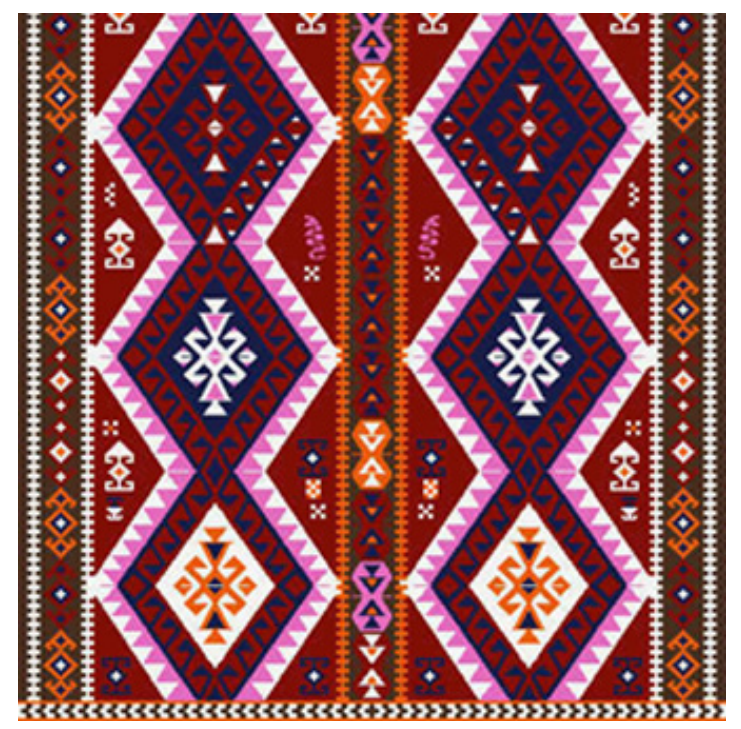

Resim 7. Resim 6'daki Beritan Kiliminin Bilgisayar Ortamında Çizimi 
Resim 8'deki Beritan kilimi $108 \mathrm{~cm}$ x $367 \mathrm{~cm}$ boyutlarındadır. Kilim tekniği ile dokunmuştur. Dokumada kenarlarda ve ortada olmak üzere 3 adet bordür bulunmaktadır. Bordürlerde küpe -nazarlık-kelebek-çocuk ${ }^{9}$ (Erbek, 2002: 74; Anatolian Kilims, 2005: 194), elibelinde ${ }^{10}$ (Türk El Dokuması Halılar, 2006, 11), koçboynuzu ${ }^{11}$, bukağı ${ }^{12}$, haç ve tarak ${ }^{13}$ motifleri kullanılmışıı (AnatolianKilims,2005: 22, 119, 176; Kayabaşı, Yanar, 2013: 181).Kilimin zemininde göz-zülüf, akrep ve yıldız motifleri hakimdir (Anatolian Kilims, 2005: 64; Durul, 1969: 24, Erbek, 2002: 132, 156). Kilimin atkı ve çözgüsü yün olmakla beraber, ortalama olarak $10 \mathrm{~cm}$ ' deki çözgü sayısı 32 tel, 10 cm' deki atkı sayısı 100 teldir. Dokumada kullanılan renkler kırmızı, açık kırmızı, lacivert, beyaz, sarı ve nohut rengidir (Resim 8-9).

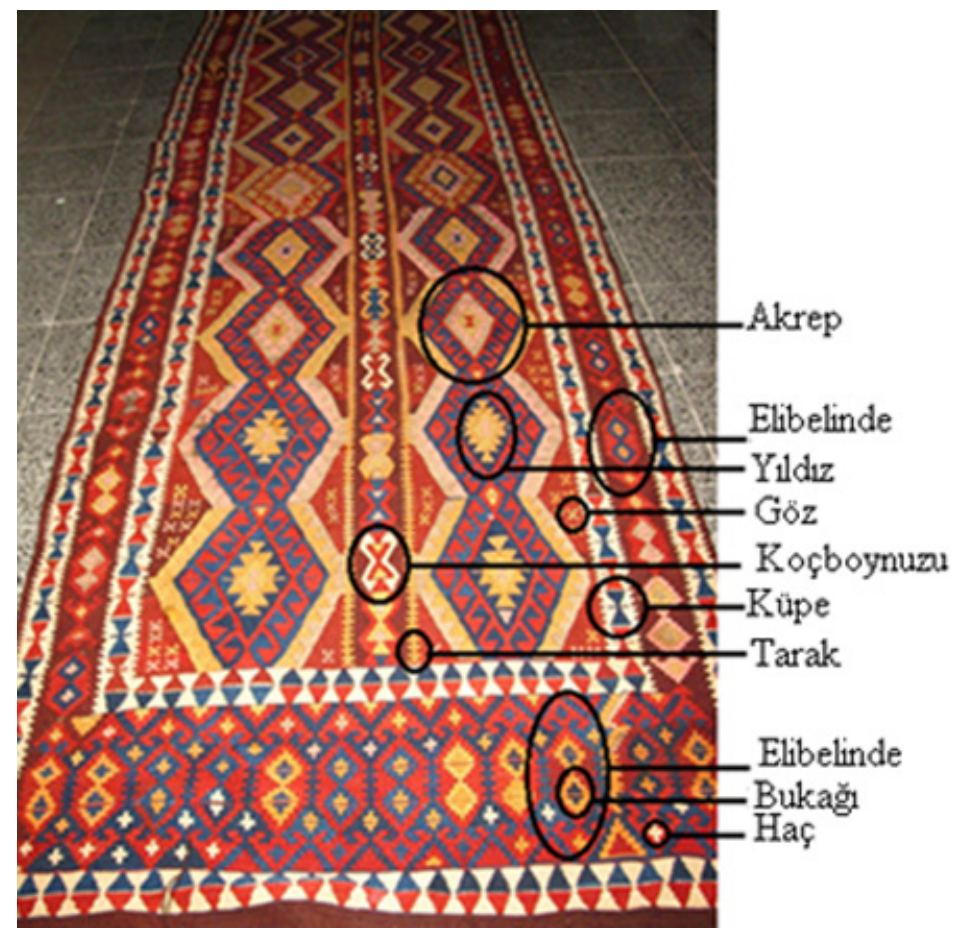

Resim 8. Beritan Kilimi, $108 \mathrm{~cm} \times 367 \mathrm{~cm}$, Elazığ, Ümmügülsüm Biçer'e ait

\footnotetext{
${ }^{9}$ T.C Kültür ve Turizm Bakanlığı, Anatolian Kilims, 2.cilt ${ }^{10}$ T.C Kültür ve Turizm Bakanlığı, Türk El Dokuması Halılar, 2. cilt

'T.C Kültür ve Turizm Bakanlığı, Anatolian Kilims, 2.cilt

${ }^{12}$ T.C Kültür ve Turizm Bakanlığı, Anatolian Kilims, 2.cilt

${ }^{13}$ T.C Kültür ve Turizm Bakanlığı, Anatolian Kilims, 2.cilt
} 


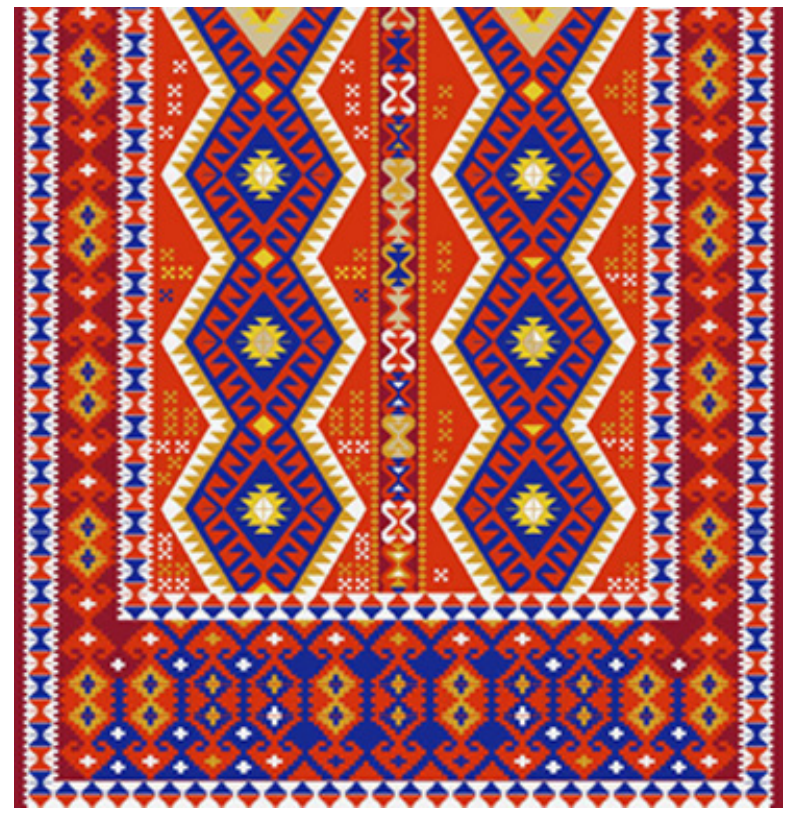

Resim 9. Resim 8'deki Beritan Kiliminin Bilgisayar Ortamında Çizimi

Resim 10'daki halı seccade $86 \mathrm{~cm} \times 159 \mathrm{~cm}$ boyutlarındadır. Halının atkı ve çözgüsü yün olmakla beraber, $10 \mathrm{~cm}$ ' de ortalama olarak atkı yönünde ilme sayısı 22 ilme, çözgü yönünde ise 28 ilmedir. Soğan kabuğu renginde olan bordüre koçboynuzu motifleri yerleştirilmiştir (Erbek, 2002: 41). Zeminde ise canavar ayakları, koçboynuzu, göz ${ }^{14}$ ve çengel motifleri görülmektedir (Türk El Dokuması Halılar, 2006: 11; Erbek, 2002: 40, 140, 161). Halıda kullanılan renkler soğan kabuğu rengi, lacivert, nohut rengi ve kremdir (Resim 10-11). 


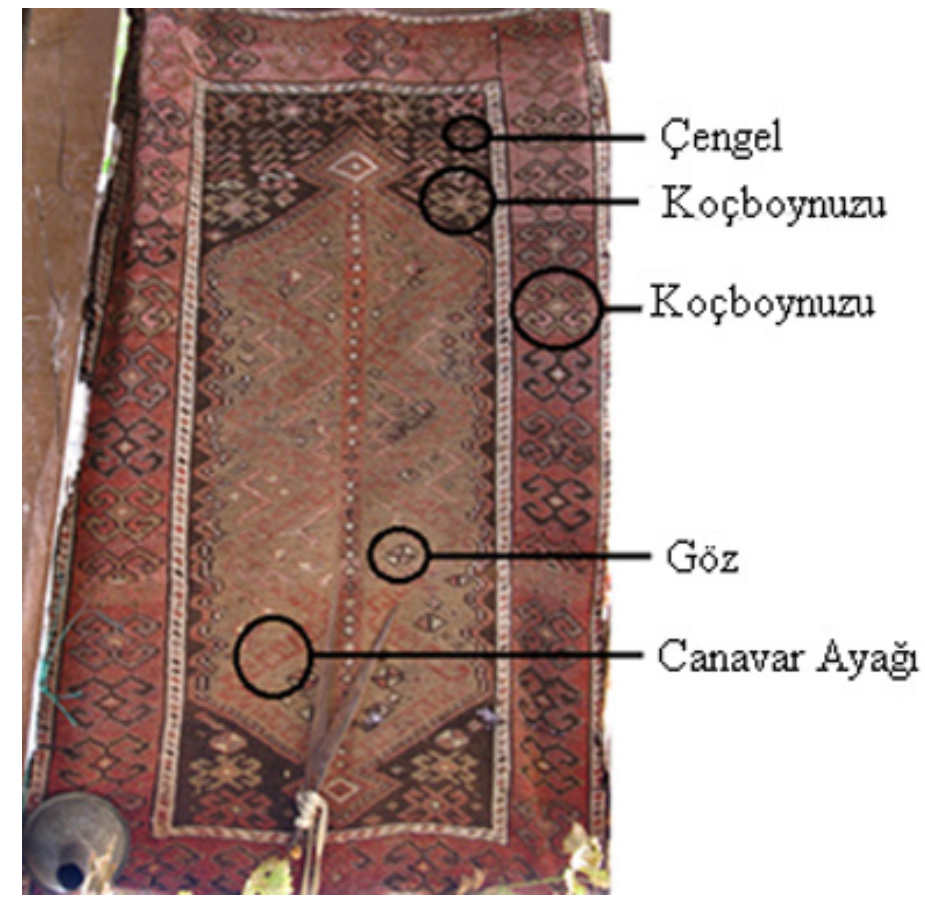

Resim 10. Beritan Halı Seccade, $86 \mathrm{~cm}$ x $159 \mathrm{~cm}$, Kovancılar, Ayşe Özkeser'e ait.

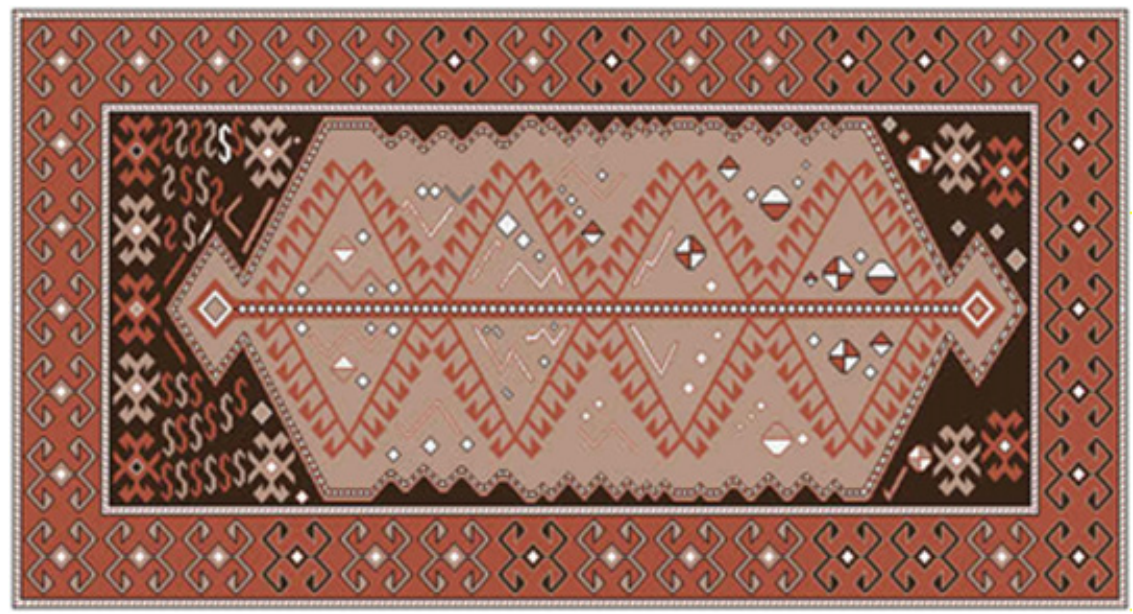

Resim II. Resim IO'daki Halının Bilgisayar Ortamında Çizimi 
Resim 12'deki seccade, tek mihraplı seccadedir. Boyutları $70 \mathrm{~cm} \times 130 \mathrm{~cm}$ olan seccadenin $10 \mathrm{~cm}$ ' de ortalama olarak atkı yönünde ilme sayısı 47 ilme, çözgü yönünde ise 34 ilmedir. Halıda nohut rengi, beyaz, kahverengi, koyu sarı, pembe, açık yeşil ve siyah renkleri hakimdir. Halıda mihrabın dışında kalan alanlarda çarkıfelek ${ }^{15}$, yıldız ve çengel (Türk El Dokuması Halılar $^{16}$, 2006: 80; Erbek, 2002: 99, 140) motifleri kullanılmıştır. Mihrabın içinde ise çarkıfelek, çengel ve yıldız motifleri görülmektedir (Resim 1213).

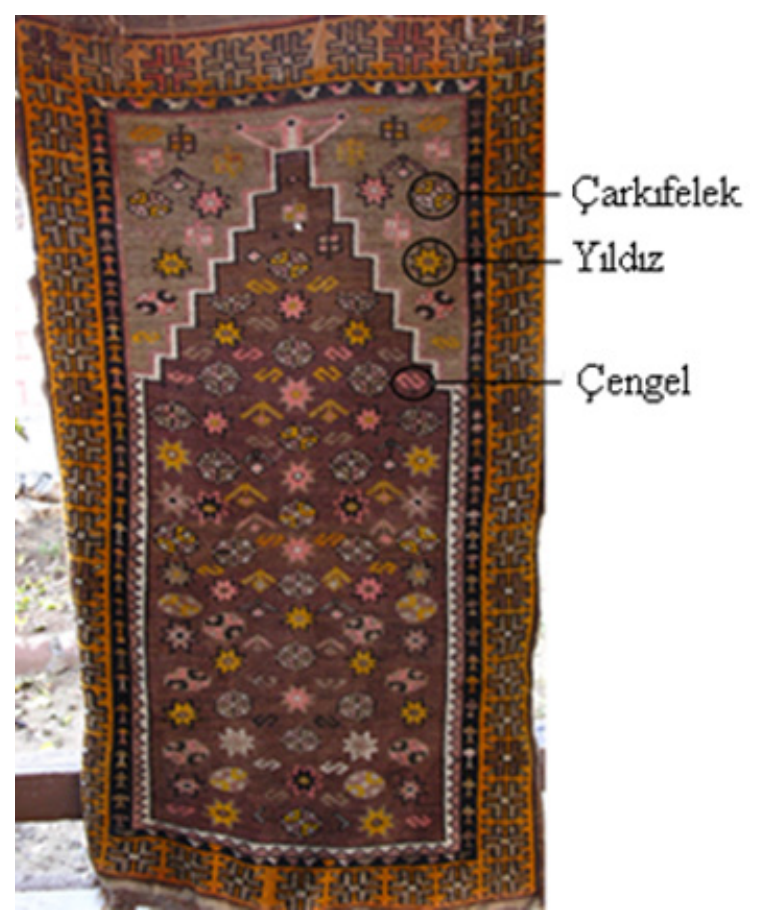

Resim 12. Beritan Halısı, $70 \mathrm{~cm} \times 130 \mathrm{~cm}$, Kovancılar, Ayşe Özkeser'e ait.

\footnotetext{
${ }^{15}$ T.C Kültür ve Turizm Bakanlığı, Türk El Dokuması Halılar, 3. cilt ${ }^{16}$ T.C Kültür ve Turizm Bakanlığı,Türk El Dokuması Halılar, 3. cilt
} 


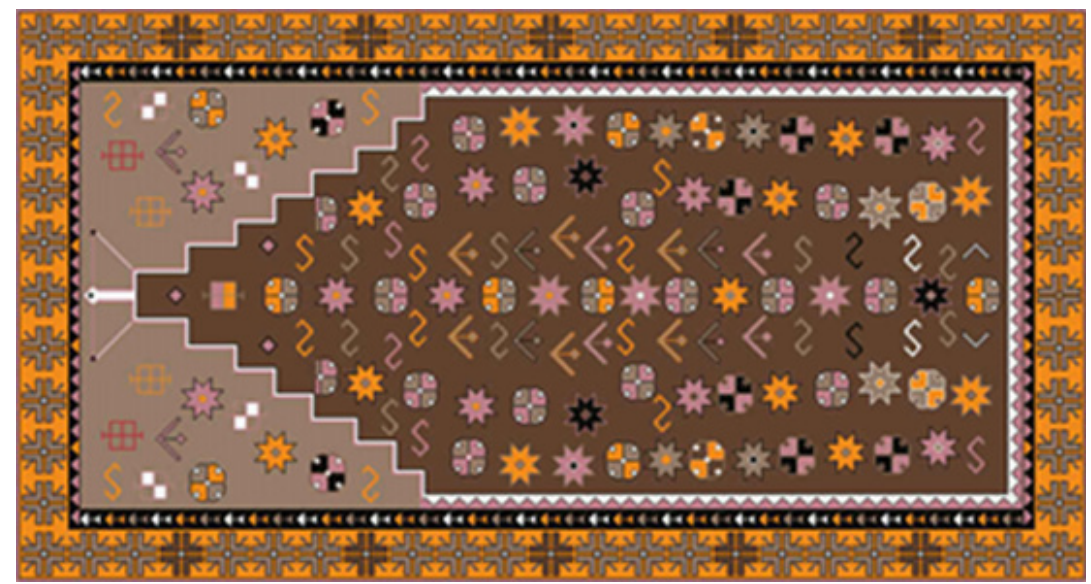

Resim 13. Resim I2'deki Halının Bilgisayar Ortamında Çizimi

\section{Tartışma ve Sonuç}

Beritan Aşireti'nin ileri gelenlerinin bir kısmı 600 yıldır Anadolu topraklarında yaşadıklarını belirtmektedirler. Doğu Anadolu, aşiretin yüzyıllardır ikamet ettiği yer olmakla beraber aşiret, daha sonraları Celali isyanları sonucu İç Anadolu bölgesine göçmüşlerdir. Burada da belli bir süre kaldıktan sonra tekrar Doğu ve Güney Doğu Anadolu topraklarına yerleşmişlerdir. Bazı kaynaklarda aşiretin kökeninin Orta Asya olduğu söylense de aşiretin ileri gelenleri bu iddia hakkında pek fazla yorum yapmamaktadırlar.

Beritan Aşireti yaylak kışlak hayatı yaşayan bir aşirettir. Aşirette kullanılan tezgâh tipi yer tezgâhıdır. Yer tezgâhının taşınmasındaki ve kurulmasındaki kolaylıklardan dolayı, yaylak kışlak hayatı yaşayan aşiretler bu tezgâh tipini tercih etmişlerdir. Aşirette eğirme, boyama ve dokuma işlemi ile kadınlar ilgilenmektedirler. Yünler Karaman koyunundan elde edilmektedir. Bir yayla dönemi içinde yapılan üretime yönelik işlemlerden birisi de hayvanların kırkılmasıdır. Koyunların ve küçükbaş hayvanların kırkımı yılda bir defa ve bahar aylarında yapılır. Kırkım sonu yapılacak işlemlerin tümü aşiret halkı tarafından yapılmaktadır.

Elazığ ve Kovancılar ilçesinde yapılan röportajlarda, incelenen dokumalardaki motiflerin yöresel adları hakkında tatmin edici bilgilere ulaşılamamıştır. Anadolu' da dokunan halı ve kilimlerdeki motifler heryörede ve literatürde farklı isimler ile anılmaktadır. Bu yüzden, bu araştırmada Beritan dokumalarında kullanılan motiflerin Anadolu dokumalarında 
görülen motiflere benzemesinden dolayı motiflere ilişkin kaynaklarda genel olarak kabul görmüş olan motif isimlerinden yararlanılmıştır. Makaleye konu olan Beritan dokumalarındaki motifler, kirkitli dokuma geleneği olan diğer bölgelerde dokunan dokumalardaki motifler ile büyük benzerlik göstermektedir. Beritan aşiretinin, dokumacılığın merkezi olan İç Anadolu bölgesine sürgün edilmesiyle birlikte, aşiret halkı bölgedeki topluluklar ile kaynaşmış, bölgeye ait dokumaların renk ve motiflerinden etkilenmiştir. Beritan dokumalarındaki motiflerin Anadolu'nun diğer bölgelerindeki motifler ile benzerlik göstermesi kültürel etkileşimin veya kültürlenmenin sonucudur.

Resim 5'teki kilim dokumasında koçboynuzu motifleri Doğu Anadolu, İç Anadolu, Akdeniz, Güney Doğu Anadolu ve Ege bölgesinde, bukağı motifi iç Anadolu, Doğu Anadolu, Doğu Karadeniz, Güney Doğu Anadolu, Akdeniz ve Marmara, göz motifi Doğu Anadolu ve iç̧ Anadolu, tarak motifi Ege, icç Anadolu, Akdeniz, Doğu Anadolu ve Karadeniz, eli belinde motifi İç Anadolu, Doğu Anadolu, Karadeniz ve Akdeniz, çengel motifi Marmara, Doğu Anadolu, İç Anadolu, Ege ve Güney Doğu Anadolu, nazarlık motifi Doğu Anadolu ve İç Anadolu, akrep motifi Doğu Anadolu bölgesindeki dokumalarda kullanılmaktadır.

Resim 7'deki kilimde göz motifi Doğu Anadolu ve İç Anadolu, tarak motifi Ege, Iç Anadolu, Doğu Anadolu, Akdeniz, Ege ve Karadeniz, eli belinde motifi İç Anadolu, Doğu Anadolu, Karadeniz ve Akdeniz, yılan motifi İç Anadolu ve Akdeniz, koçboynuzu Doğu Anadolu, iç Anadolu, Akdeniz, Güney Doğu Anadolu ve Ege, akrep Doğu Anadolu bölgelerindeki dokumalarda görülmektedir.

Resim 10'daki kilim dokumasında akrep Doğu Anadolu, eli belinde İç Anadolu, Doğu Anadolu, Karadeniz ve Akdeniz, yıldız motifi İç Anadolu, Akdeniz, Marmara, Doğu Anadolu, koçboynuzu motifi Doğu Anadolu, Iç Anadolu, Akdeniz, Güney Doğu Anadolu ve Ege, tarak motifi Ege, i̇ç Anadolu, Akdeniz, Doğu Anadolu ve Karadeniz, eli belinde motifi İç Anadolu, Doğu Anadolu, Karadeniz ve Akdeniz, bukağı motifi İç Anadolu, Doğu Anadolu, Doğu Karadeniz, Güney Doğu Anadolu, Akdeniz ve Marmara, çengel motifi Marmara, Doğu Anadolu, İç Anadolu, Ege ve Güney Doğu Anadolu, koçboynuzu motifi Doğu Anadolu, İç Anadolu, Ege, Doğu Karadeniz ve Batı Anadolu bölgelerindeki dokumalarda kullanılmaktadır.

Resim 12'deki halı seccadede çengel motifi i̇ç Anadolu, Marmara ve Doğu Anadolu, bordürdeki koçboynuzu motifi iç̧ Anadolu, Doğu Karadeniz, Doğu Anadolu, canavar ayakları İç Anadolu, halı zemininde 
kullanılan koçboynuzu ve göz motifleri İç Anadolu bölgelerinde dokunan dokumalarda görülmektedir.

Resim 13'teki halı seccadede bulunan çarkıfelek motifi iç Anadolu bölgesinde görülmekle beraber, yıldız ve çengel motifleri de Anadolu'nun birçok bölgesinde sevilerek dokunan motiflerdir.

Anadolu dokumaları ile Beritan dokumalarının arasındaki dokuma tekniğinin (ilmelerin soldan sağa atılması = Batı Anadolu tipi), motif ve renklerinin benzerliklerine dayanarak Beritanlıların Türkmen oldukları ve Orta Asya'dan Anadolu'ya gelerek kendilerine özgü motif ve kompozisyon anlayışlarını yerleştikleri yerlerde uyguladıkları sonucuna varılmaktadır. Beritan Aşireti'nin Anadolu'da yaşayan toplumlarla bir araya gelerek kültür, adet, gelenek, görenek, sanat ve yaşam tarzı gibi insandan insana geçen davranışlar ile birbirlerini beslediği ve etkileşim kurduğu kuvvetli bir olasilıktır.

Günümüzden 20 yıl öncesine kadar Beritanlı kadınlar evlerini süslemek, çadırlarında kullanmak ve kızlarına çeyiz vermek amacı ile dokuma yapmaya devam etmekteydi. Aşiretin eskiden sadece kendi ihtiyaçlarını karşılamak için ürettikleri dokumalar günümüzde kentsel ekonomiye geçiş, makine halıcılığının yaygınlaşması, dokuma işinin zor bir iş olması, gençlerin kentlere iş ve eğitim için gitmeleri ve dokuma işi ile uğraşmak istememeleri nedeni ile bu dokumalar kaybolup gitmiştir. Ayrıca Elazığ ve Kovancılar ilçesinde yapılan araştırmalar sonucunda makalede incelenen Beritan dokumalarının dışında başka dokumalara rastlanılmamıştır.

Günümüzde havlı ve havsız dokumalarla ilgili en büyük sorun yöresi ne olursa olsun Beritan Aşireti örneğinde olduğu gibi aşiretlere ait dokumalara gerektiği önemin ve özenin gösterilmemiş olmasıdır. Sahip olunan bu değerlerin, envanter kayıtlarının tutulması ve yazılı bilgi aktarımının yapılması son derece önemlidir. Dolayısıyla bu eserler görsel malzemenin de aktarılmasıyla gelecek kuşaklara ve genç araştırmacılara aşiretlerin yaşayış ve kültürünü öğretmede kaynak olacaktır. Bu yüzden Beritan Aşireti dokumalarının korunması ve yaşayabilirliğinin sağlanması için eserlerin kimliklerinin saptanması ve belgelenmesi gerekmektedir. 


\section{Kaynakça}

Aktan, A. (1995). “Anadolu’da Avşarlar”, Erciyes Üniversitesi Sosyal Bilimler Dergisi, 6, 255-262

Aksoy, E. (20I2). “Beritan Aşireti Çözgü Yüzlü Cicimleri”, Batman University International Participated Science and Culture Symposium (ss. 30I-309), Batman.

Anatolian Kilims. (2005). Ankara: T.C. Kültür ve Turizm Bakanlığı Basımevi.

Atalay, B. (2006). DivanüLügati't - Türk. Ankara: Türk Tarih Kurumu Basımevi.

Beşikçi, i. (1969). Doğu'da Değişim ve Yapısal Sorunlar. Ankara: Doğan Yayınevi.

Biçer Ümmügülsüm (20I4, 10 Kasım). Beritan aşireti dokumaları üzerine söyleşi.

Canpolat i. (20/4, 25 Ekim), Beritan aşireti üzerine söyleşi, Canpolat’in Ofisi, Elazı̆̆.

Durul, Y. (1969). Baraj Gölü Çevresi Dokuma Sanatları. Ankara: Orta Doğu Teknik Üniversitesi Keban Projesi Yayınları.

Erbek, M. (2002). Çatalhöyük'ten Günümüze Anadolu Motifleri. Ankara: T.C. Kültür Bakanlı̆̆ı Yayınları

Erenoğlu, E, H. (20I0). Halil Erenoğlu’nun Emirdă̆ yazıları, Eskişehir: SBL Yayıncılık.

Erhan, S. (1992). Identity Formation and Political Organization Among Anatolian Nomads: The Beritanlı Case, Doctorate Thesis, The University of Texas at Austin.

Eşberk, T. (1939). Türkiye'de Köylü El Sanatlarının Mahiyeti ve Emniyeti. Ankara: Recep Ulusoğlu Basımevi.

Gül, Y. (1976). Tunceli’de Şavaklılar. Ankara: Şafak Matbaası.

Haack, H. (1975). Doğu Halıları. Ankara: Baylan Matbaası.

Hadimli H., Karakuzulu Z., Birinci S. (20I0). "Akseki ilçesindeki Göçebe Hareketler”, Uluslararası Sosyal Araştırmalar Dergisi, Cilt: 3/10, 348-359.

Ipek N., Şimşirgil A., Gülsoy, E. Taştemir, M. (20/3). “Osmanlı’da İskân ve Göç”, T.C. Anadolu Üniversitesi Yayını, 76.

Kantarcıoğlu Bozan (20/4,I0 Kasım). Beritan aşireti üzerine söyleşi, Kantarcıoğlu’nun arşivinden

Kayabaşı, N., Yanar, A. (20I3). “Türk El Sanatlarında Kullanılan Nazar Motiflerive Alevilerde Nazar Inancı”, Türk Kültürü ve Hacı Bektaşi Veli Araştırma Dergisi, 65, I69-I84. 
Kır I. (2003). "Barak Aşireti”, Fırat Üniversitesi Ortadoğu Araştırmaları Dergisi, I (I), 2 I9240.

Kongar, E. (1994). Kültür Üzerine. İstanbul: Remi Kitabevi.

Kutlu, M. (1987). Şavaklı Türkmenlerde Göçer Hayvancılık. Ankara: Kültür ve Turizm Bakanlı̆̆ı.

Melikoff, I. (1998). Bektashi/Kızılbaş: Historical Bipartition and Its Consequences, in T. Olsson, E. Özdalga \& C. Raudvere (eds) Alevi Identity: Cultural, Religious and Social Perspectives, Swedish Research Institute in Istanbul, Numune MatbaasI, I- IO

Mutlu, H. K. (20I I). “Balıkesir ve Batı Anadolu Yöresi Tahtacı Türkmenleri”, Turkish Studies - International Periodical for the Languages, Literature and History of Turkish, 6/I:15031511

Özkeser, Ayşe (20I4, 10 Kasım) Beritan aşireti dokumaları üzerine söyleşi.

Skogseid, H. (1993). Nomadic Pastoralism and Land use Patterns in Eastern Turkey. H. Palva and K.S. Vikor (eds). The Middle East-Unity and Diversity, Nordic Proceedings in Asian Studies No. 5, Copenhagen: Nordic Institute Asian Studies. 216-23I.

Sorgucu S. (20/4, I6 Ekim). Beritan aşireti dokumaları üzerine röportaj, Sorgucunun Ofisi

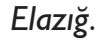

Stocking, W.G. (1968). Race, Culture, and Evolution, London: The University of Chicago Press.

Sümer, F. (1957). “Azerbaycan'ın Türkleşmesi Tarihine Umumi Bir Bakış”, Belleten, 83 (I 3), 429-447; Woods, J. E. (1999). Aqquyunlu: Clan, Confederation, Empire, Minneapolis and Chicago. 2nd edition, Salt Lake City: University of Utah Press.

Taşdelen, H, M. (1997). Göçerlerin Şehirleşmesi (Beritan Aşireti Örneği).İstanbul: Turan yayıncilık.

Türk El dokuması Halılar. (2006). Ankara: T.C. Kültür ve Turizm Bakanlığı.

Yağan, Ş. (1978). Türk El Dokumacılı̆̆ı. Isstanbul: Türkiye Iş Bankası Kültür Yayınları.

Yalgın, A. R. (1977). Cenupta Türkmen Oymakları. Ankara: Kültür Bakanlığı Yayınevi. 


\section{İnternet Kaynakları}

Internet: Balıkçı F. (2000). Beritans settling, in Hurriyet Daily http://www. hurriyetdailynews. com/beritans-settling.aspx?pagelD $=438 \& n=$ beritans-settling-2000-06-08 adresinden 14 Ocak 2015'te alınmıştır.

\section{Görsel Kaynaklar}

Resim I. Thevenin, M. (20II). "Kurdish Transhumance: Pastoral practices in South-east Turkey", Pastoralism, I(I), I-24.

Resim 3. Aytaç, A. (2000). Geleneksel Türk El Dokumacılığı sanatı. Konya: Selçuk Üniversitesi Yayınları

Resim 4-6. Bozan Kantarcıoğlu'nun Arşivinden.

Resim 8. Ümmügülsüm Biçer'in Arşivinden.

Resim 10-12. Ayşe Özkeser'in Arşivinden. 